\title{
Umbilical Cord Blood Hematopoietic Stem Cell Expansion Ex Vivo
}

\author{
Zhihua Ren ${ }^{1}$ and Yongping Jiang ${ }^{2 *}$
}

${ }^{1}$ Biopharmagen Corp., Suzhou, China

${ }^{2}$ Biopharmaceutical R\&D Center, Chinese Academy of Medical Sciences \& Peking Union Medical College, Suzhou, China

\begin{abstract}
Umbilical cord blood is an attractive source of hematopoietic stem and progenitor cells in the treatment of hematologic diseases, especially in allogeneic hematopoietic cell transplantation. However, due to the low abundance of these cells, the therapeutic use of umbilical cord blood has been limited mostly to the pediatric setting. The strategies for adult umbilical cord blood transplantation have been improved, with the recent development of various approaches for expanding stem cells in vitro and enhancing their long-term homing efficiency. In this brief review, we discuss a number of strategies for stimulating the proliferation of umbilical cord blood hematopoietic stem cells in vitro, including the utility of transcription factors and growth factors (cytokine cocktails), as well as co-culturing with stromal cells. Ultimately, we make the case that improvements in umbilical cord blood stem cell expansion will be critical for enhancing transplantation engraftment efficacy and providing potential cure for hematological diseases.
\end{abstract}

Keywords: Umbilical cord blood; Stem cell; Hematopoietic; Cytokine

\section{Introduction}

Umbilical cord blood (UCB) has been considered as an attractive source of hematopoietic stem cell, which offers an alternative approach to bone marrow transplantation in the treatment of both malignant and non-malignant hematologic diseases [1-7]. As early as 1939, scientists have predicted that UCB could be applied to therapeutic use. However, UCB transplantation was not successful until 1988 [2]. As perhaps the largest source of stem cells available, the UCB, normally discarded, has recently been used worldwide for transplantation, especially allogeneic transplantation, to treat patients. By now, more than 25,000 transplantation procedures have been performed, and approximately 500,000 UCB units have been donated and banked for public use [5,8-10]. Generally speaking, UCB transplantation has at least two advantages over bone marrow transplantation [5,8-12]. First, it has much lower risk of acute and chronic graft-versus-host diseases (GVHD), which could lead to morbidity and mortality. Second, it has a lesser requirement for HLA-antigen matching (e.g., only 2 of the 6 HLA $-\mathrm{A}$ or $\mathrm{B}$ loci). However, there are also two significant challenges for the UCB transplantation, especially in adult patients $[12,13]$. First, UCB has a limited number of stem cells and colony-forming activity. Considering an adult's body mass, one single unit of UCB is far inadequate to provide sufficient numbers of stem cells for transplantation in an adult patient. Approximately $2-3 \times 10^{\wedge} 8$ total nucleated cells could be harvested in an unit of UCB, while the recommended total number of nucleated cells for transplantation to an adult is $2 \times 10^{\wedge} 7 / \mathrm{kg}$, minimum. Second, UCB transplantation is associated with delayed engraftment and immune reconstitution (as indicated by recovery in neutrophil and platelet counts), as well as delayed post-transplantation recovery, due to a lack of sufficient amounts of progenitor cells to sustain the therapy.

To improve the outcome of UCB transplantation in adult patients, one potential solution is to extensively expand UCB stem cells ex vivo [14-18]. Such expansion would not only augment stem cell abundance, but it would also facilitate cell homing in mismatched UCB transplantation, by overcoming HLA mismatch [19]. Either in single or double UCB transplantation trials, clinical data indicated that the greater the mismatch of HLA antigens, the greater the requirement for higher doses of donor total nucleated cells. For example, units of UCB that were 2/6 HLA-mismatched to the recipient required greater than $5.0 \times 10^{\wedge} 7 / \mathrm{kg}$ total nucleated cells to achieve a comparable outcome to that achieved by units that were $1 / 6$ HLA-mismatched, at $2.5 \times 10^{\wedge} 7 / \mathrm{kg}$ total nucleated cells [20-22].

Various approaches to achieve higher abundance of hematopoietic stem cells and progenitors for infusion have been explored and tested in in-vivo or clinical trials [23-30]. McNiece and co-workers succeeded in maintaining the long-term repopulation capability of HSC in culture, and achieving hematopoietic recovery when applying ex vivo manipulated HSC to a fetal sheep model [29]. Von Drygalski et al. further demonstrated in a mouse model that the bone marrow long-term engraftment potentials could be sustained following exvivo expansion [30]. Delaney et al. reported even more promising data in a phase I cord blood transplantation trial [31], where the time to neutrophil recovery was substantially shortened by transplanting $e x$ vivo expanded cord blood progenitors along with un-manipulated UCB. Following the primary UCB cell infusion, 9 out of 10 patients who received a secondary infusion of manipulated HSC attained ANC (absolute neutrophil count) $>500 / \mu$ with a medium time of 16 days, whereas 20 patients in a concurrent cohort who receive a secondary infusion of non-manipulated HSC attained the same ANC with a medium time of 26 days; the two cohorts were treated under identical conditions in the primary infusion and post-transplant immunosuppressive regimen.

There is strong indication that ex-vivo expanded HSCs have the potential to facilitate engraftment of un-manipulated UCB cells, but they are not necessarily the source of long-term hematopoietic recovery

*Corresponding author: Yongping Jiang, Biopharmaceutical R\&D Center, Chinese Academy of Medical Sciences \& Peking Union Medical College Suzhou, China 215126, Tel: 86-512-63851269; Fax: 86-512-63851219; E-mail: yjiang9999@biopharmagen.com

Received July 22, 2013; Accepted August 07, 2013; Published August 09, 2013

Citation: Ren Z, Jiang Y (2013) Umbilical Cord Blood Hematopoietic Stem Cell Expansion Ex Vivo. J Blood Disorders Transf S3: 004. doi:10.4172/2155-9864. S3-004

Copyright: @ 2013 Ren Z, et al. This is an open-access article distributed under the terms of the Creative Commons Attribution License, which permits unrestricted use, distribution, and reproduction in any medium, provided the original author and source are credited. 
$[25,29,32,33]$. Hence, although the main purpose to expand UCB is to provide adequate number of HSC for primary transplantation, the amplified HSC could also be applied for supportive therapy after the primary transplantation, thus further reducing the risk of GVHD associated with infusion of cells from another mismatched donor. Additionally, the combinatorial administration of expanded and nonexpanded HSC also improves outcome in clinical trial by accelerating graft homing.

A number of current ex-vivo expansion strategies are described below. These approaches have been extensively studied and applied in clinical trials worldwide [23-28].

\section{Methods}

\section{Cytokine combination mediated expansion}

The methods of culturing UCB cells with addition of various cytokine combinations have been extensively investigated, though an ideal cocktail recipe has yet to be reported. As it is well known, the fates of HSC are determined by a variety of cytokines and growth factors that are generated endogenously by the bone marrow. Research scientists and clinical providers have tried to mimic this endogenous micro-environment, and have succeeded in amplifying the primitive hematopoietic stem cells/progenitors in the presence of various growth factors. In this approach, which has been proven to be a safe and stable way to obtain sufficient number of graft [34], the hematopoietic progenitors $(\mathrm{CD} 34+)$ were isolated, before ex vivo culture, with use of a clinical-grade magnetic beads system (e.g., the Miltenyi CliniMACS system). Generally, a purity of greater than $90 \%$ CD $34+$ cells could be reached on culture day 0 , before the HSCs were incubated with various cytokine, either alone or in combination [35]. Factors that have been utilized to promote expansion of HSC include Flt-3 ligand, SCF, G-CSF, TPO, IL-3, IL-6, and IL-11 [25-27,30,36-44]. The mechanisms by which these factors maintain stem cell proliferation potentials are not yet clear and sometimes controversial. Research data indicated that Flt- 3 and TPO might prevent telomere degradation $[39,45]$; whereas SCF and IL-6 stimulate the proliferation of HSCs and maintain their long-term repopulation capabilities [46-48].

To gain a maximal fold of HSC expansion ex vivo, various concentrations of cytokines have been tested by our lab $[49,50]$ and several other groups. Shpall et al. reported a clinical study showing that, when HSCs were cultured with SCF, TPO, and G-CSF supplements (each at $100 \mathrm{ng} / \mathrm{ml}$ ), they underwent a 4 -fold (median, range 0.1-20) increase in CD34+ cells, and a 56-fold (median, rang 1.03-278) increase in TNC, by 10 days in culture [24]. McNiece et al. further improved the expansion protocol, achieving a $>20$-fold increase in CD34+ cells and a $>400$-fold increase in TNC, by day 14 in culture, with use of the same cytokine supplements (SCF, TPO, G-CSF) [37]. We have also attempted to optimize the ex vivo culture system, in order to enhance HSC expansion at even greater efficiency. Cytokines, including Flt-3, SCF, and G-CSF, were included in our custom-made basal medium, and various doses of each of the cytokines were tested over a period of 14 days in culture. Our preliminary data (unpublished) demonstrated that a $>60$ fold increase in CD34+ cells and a $>600$-fold increase in TNC could be achieved, thus providing a promising approach to expand CD34+ cells for further pre-clinical studies. The cytokine combinations supported not only a short-term HSC expansion ex vivo in an undifferentiated state; they also shortened the UCB engraftment time.

\section{SALL4 signaling pathway mediated expansion}

Over-expression of SALL4, an embryonic stem cell factor, has been reported recently as a novel approach to proliferating hematopoietic stem cells ex vivo. Originally, SALL4 was found to be expressed in human leukemia cell lines and primary acute myeloid leukemia cells [51-55]. Aguila et al. and others showed that SALL4 plays a critical role in maintaining the multiple potential and in governing decisions affecting the fate of HSCs through transcriptional modulation and interaction with OCT-4 and Nanog [52,56,57]. Lenti-viral SALL4B over-expression lead to a more than 10000-fold expansion of human HSCs in the presence of appropriate cytokines (TPO, FLt-3, SCF), with enhanced stem cell repopulation capacity in vivo. To develop a clinically applicable protocol utilizing SALL4B factors, the investigators generated a recombinant TAT-SALL4B protein that is capable of promoting human HSC expansion ex vivo [57]. Further pre-clinical studies and clinical trial are required to support these results.

\section{Notch signaling pathway induced expansion}

Accumulating evidence from multiple clinic centers has shown that Notch ligand, Delta-1, Jagged-1 and Jagged-2, contribute to a rapid early engraftment of UCB progenitors, as well as regulate HSC proliferation and hematopoietic cell fate decision [58]. Initial studies using soluble or cell-bound Notch ligand indicated limited expansion effects on progenitors in murine model and humans [59-61]. Investigators further revealed that ligand immobilization was required for Notch signaling pathway activation $[62,63]$, which leads to marked HSC proliferation and shortened lymphoid and myeloid repopulation [31]. Based on that knowledge, researchers, by culturing human cord blood C34+CD38cells with immobilized ligand and cytokines in serum free conditions, were able to gain approximately 100-200 fold increases in CD34+ cells, which were functional for reconstitution in an immune-deficient mice model $[64,65]$. More recently, based on pioneering studies by Wagner et al., who demonstrated safety of double cord blood unit infusion [66], Delaney et al. applied the Notch ligands-expanded UCB cells along with un-manipulated HSC to patients undergoing myeloablative regimen, and achieved a quite favorable outcome [31, 67]. CD34+ enriched UCB cells were cultured with Notch ligand Delta-1 and serum free media supplemented with SCF, TPO, FLt-3, IL-3, and IL-6 for 16 days, and approximately 164 fold expansion of CD34+ cells (Range: 41-471) and an average of 562 fold expansion of total cells (Range: 146-1496) were achieved. The expanded cells were used for graft infusion in ten patients with high risk acute leukemia and morphological remission. However, it appeared that variations in the densities of Notch ligands might result in different cell-fate outcomes [64]. Low density Delta-1 stimulated proliferation of CD34+ cells, whereas high-dose Delta-1 induced apoptosis of CD34+ precursors, resulting in decreased cell numbers.

\section{Co-culture with stromal cells}

Naturally, the hematopoietic stem cells in bone marrow are maintained and regulated by a specific microenvironment referred to as "niche" [68]. Therefore, extensive studies have been carried out to co culture HSCs with stromal cells, in order to recreate their niches and gain UCB stem cell expansion ex vivo [69,70]. In addition to providing direct support to HSCs, stromal cells are known to secret a number of cytokines and adhesion molecules at high levels, including osteopontin (OPN), angiopoietin 1(Ang-1), thrombopoietin (TPO), Jagged-1, CXC chemokine ligand 12 (CXCL12, also known as SDF1), G-CSF, GM-CSF, SCF, and IL-6 that can contribute to HSCs' proliferation and differentiation [71-77]. Dexter demonstrated that an adherent 
stromal-like co-culture system was able to sustain the self-renew properties of hematopoietic stem cells as well as early B lymphopoeisis [78]. Researchers revealed that ablation of those stromal cells in bone marrow significantly decreased the HSC numbers and reduced HSC homing to bone marrow by $90 \%$ [79].

A variety of stromal cells have been studied as matrices for ex vivo expansion of HSC, including MSCs isolated from bone marrow [80-82], adipose tissue [83-85], placenta [86], umbilical cord blood [87-89], umbilical cord tissue (Wharton's Jelly) [90-94], and fetal liver [95]. Bone marrow-derived mesenchymal stem cells have been widely used and clinical-scale UCBMNC-BMMSC in vitro co-culture procedures were well developed [96] and validated [97]. Clinical trials have been designed accordingly utilizing autologous [80,98] or related family member donor [97,99] (matched at $\geq 2 / 6$ HLA antigens) bone marrow MSC for UCB co-culture. The MSC were grown to $>70 \%$ confluence and then co cultured with UCB total nuclear cells for 7 days, in the presence of the following cytokines $(100 \mathrm{ng} / \mathrm{ml}$ each of SCF, FLt-3 ligand, G-SCF, and TPO). Non-adherent cell were removed from each flask and transferred into individual culture system with MSC conditioned medium for additional 7 days (totally 14 days), achieving approximately 12 fold increase in CD34+ cells and 12-fold increase in total nuclear cells. However, functional and phenotypic heterogeneity have been observed within primitive hematopoietic stem cells/progenitors [100-104]. Most MSC-UCB co-cultures were established on bone marrow MSCs with exogenously added cytokines to promote HSC proliferation; the resulting cells have been referred to as "lower quality" hematopoietic progenitors contributing to short term reconstitution $[32,103,104]$. Evidence from both animal models and clinical trials indicated that ex vivo expanded CD34+ cells sometimes do not support long-lasting engraftment [29,30,33,36,105109]. Currently, greater efforts are dedicated to maintaining HSC "stemness property", or their CD34+CD38-phenotype, which has been considered to be the marker for the subpopulation that contains the highest clonogenic activity [110-113]. Others have reported that CD34+c-kit+HLA-DR could represent high proliferative potential colony-forming cell and long-term BM culture initiating cells [114117]. Rodriguez-Pardo et al. reported recently that a higher percentage of CD34+CD38- cells were observed on day 7 in a BM-MSC co culture system, when cultured without, than with, cytokine supplements [82]. Isern et al. described a new method of isolating and culturing human BMMSCs as non-adherent mesenchymal spheres, which presented relatively undifferentiated phenotypes; this method supported high efficiency expansion of HSC through secreted soluble factors, and it did not rely on cell-to-cell contact [118]. Both in vivo and in vitro studies demonstrated that these MSC spheres yielded a much greater extent of expansion of UCB CD34+ cells (40-fold versus 6-fold), as well as significantly increased long-term human HSC engraftment in murine model, when compared with regular plastic-adherent BM MSCs.

Even though bone marrow derived stromal cells have been extensively used as the feeder cell for HSC Co-culture, the BMMSCs also have limitations [99]. These limitations include: 1), a suitable family member is not always available to donate bone marrow; 2 ), time taken to generate adequate BMMSCs (about 3 weeks); and 3), time required to produce sufficient amount of HSCs via co-culture (2 more weeks). In addition, BM MSC harvesting is a painful and high risk procedure to donor. Therefore, clinicians and researchers have been seeking alternative and optimal cell sources to be used as "off-the-shelf" MSC for clinical trials. In that regard, the Simmons lab developed the stro-1 antibody, which allowed prospective isolation of human bone marrow cells from young, healthy volunteers, and the development of the angioblast MSC master cell banks [119]. Preliminary clinical study revealed no difference in performance between expanded UCB product and angioblast MSC product from normal donor-derived MSCs.

Another attractive source of MSC is umbilical cord tissue, known also as Wharton's Jelly [120]. The beneficial properties of this latter source of cells include: 1 ), sufficient amounts of MSCs, at least $4.6 \times 10^{\wedge} 6$ cells, can be isolated from $1 \mathrm{~cm}$ of umbilical cord, and the stemness properties of these cells lasted longer than bone marrow MSCs in culture (10 passage versus 3 passage) [94]; 2), they are hypoimmunogenic (which alleviates concerns of GVHD) and thus can be used in autologous or allogeneic settings [91]; 3), they have high thaw-survival rates ( 90\%), which makes them a reliable MSC cell source [94]. Studies to date have shown that Wharton's Jelly-derived MSC promoted HSC proliferation through secretion of various factors, including interleukin family (IL1a, IL-6, IL-7, IL-8), hyaluronic acid, cell adhesion molecules, cadherins, and growth factors (SCF, HGF), at much higher levels than by bone marrow derived MSCs [121,122]. Being naturally rich and hypoimmunogenic, Wharton's Jelly-MSCs-conditioned medium alone seems to serve as a better support to expanding stem cells than could long term cultureinitiating cells and colony forming cells, and can potentially bring about even greater desirable effects in clinical study.

\section{Summary}

Umbilical cord blood has been well recognized as an alternative donor source of HSCs for allogeneic transplantation to treat malignant and non-malignant hematopoietic diseases. However, particularly for adult patients, UCB transplantation has been limited by the low dose of HSCs available in each graft, which leads to delayed myeloid and lymphoid engraftment. Current strategies to overcome this limitation include ex vivo expansion, infusion of two UCB units, and co-transplantation with mesenchymal stem cells (suitable for immunomodulation and prevention of GVHD), which could be applied individually or in combination to enhance homing and longterm engraftment. Ample clinical trials have shown that expanded UCB cells are safe for transplantation, and favorable outcomes have been achieved due to increased progenitor infusion and facilitated engraftment. Further efforts are being undertaken to identify the optimal expansion conditions, include the use of cytokines, stroma coculture, and novel signaling pathway stimulation, to preserve primitive hematopoietic progenitor properties. Overall, expectations remain high that eventually ex vivo expansion of UCB will be able to improve clinical outcomes and benefit more patients.

\section{Acknowledgement}

We thank Dr. Xinxin Ding for useful discussion and editing the manuscript. This work is supported in part by the State New Drug Research \& Development (2011ZX09401-027; 2011ZX09102-010-04; 12C26213202208)

\section{References}

1. Hough R, Rocha V (2010) Transplant outcomes in acute leukemia. II. Semin Hematol 47: 51-58.

2. Gluckman E, Broxmeyer HA, Auerbach AD, Friedman HS, Douglas GW, et al. (1989) Hematopoietic reconstitution in a patient with Fanconi's anemia by means of umbilical-cord blood from an HLA-identical sibling. N Engl J Med 321: 1174-1178.

3. Wagner JE, Kernan NA, Steinbuch M, Broxmeyer HE, Gluckman E (1995) 
Allogeneic sibling umbilical-cord-blood transplantation in children with malignant and non-malignant disease. Lancet 346: 214-219.

4. Locatelli F, Rocha V, Reed W, Bernaudin F, Ertem M, et al. (2003) Related umbilical cord blood transplantation in patients with thalassemia and sickle cell disease. Blood 101: 2137-2143.

5. Liu Y, Hangoc G, Campbell TB, Goodman M, Tao W, et al. (2008) Identification of parameters required for efficient lentiviral vector transduction and engraftment of human cord blood CD34(+) NOD/SCID-repopulating cells. Exp Hematol 36: 947-956.

6. MacMillan ML, Walters MC, Gluckman E (2010) Transplant outcomes in bone marrow failure syndromes and hemoglobinopathies. Semin Hematol 47: 37-45.

7. Kurtzberg J, Prasad VK, Carter SL, Wagner JE, Baxter-Lowe LA, et al. (2008) Results of the Cord Blood Transplantation Study (COBLT): clinical outcomes of unrelated donor umbilical cord blood transplantation in pediatric patients with hematologic malignancies. Blood 112: 4318-4327.

8. Rocha V, Broxmeyer HE (2010) New approaches for improving engraftment after cord blood transplantation. Biol Blood Marrow Transplant 16: S126-132.

9. Rocha V, Gluckman E; Eurocord-Netcord registry and European Blood and Marrow Transplant group (2009) Improving outcomes of cord blood transplantation: HLA matching, cell dose and other graft- and transplantationrelated factors. $\mathrm{Br} \mathrm{J}$ Haematol 147: 262-274.

10. Broxmeyer HE (2010) Umbilical cord transplantation: epilogue. Semin Hemato 47: 97-103.

11. Rocha V, Locatelli $F(2008)$ Searching for alternative hematopoietic stem cell donors for pediatric patients. Bone Marrow Transplant 41: 207-214.

12. Cohen G, Carter SL, Weinberg KI, Masinsin B, Guinan E, et al. (2006) Antigenspecific T-lymphocyte function after cord blood transplantation. Biol Blood Marrow Transplant 12: 1335-1342.

13. Eapen M, Rubinstein P, Zhang MJ, Stevens C, Kurtzberg J, et al. (2007) Outcomes of transplantation of unrelated donor umbilical cord blood and bone marrow in children with acute leukaemia: a comparison study. Lancet 369: 1947-1954.

14. Weinreb S, Delgado JC, Clavijo OP, Yunis EJ, Bayer-Zwirello L, et al. (1998) Transplantation of unrelated cord blood cells. Bone Marrow Transplant 22: 193196.

15. Barker JN, Weisdorf DJ, Wagner JE (2001) Creation of a double chimera after the transplantation of umbilical-cord blood from two partially matched unrelated donors. N Engl J Med 344: 1870-1871.

16. Barker JN, Weisdorf DJ, DeFor TE, Blazar BR, Miller JS et al. (2003) Rapid and complete donor chimerism in adult recipients of unrelated donor umbilical cord blood transplantation after reduced-intensity conditioning. Blood, 102: 19151919.

17. De Lima M, St John LS, Wieder ED, Lee MS, McMannis J, et al. (2002) Doublechimaerism after transplantation of two human leucocyte antigen mismatched, unrelated cord blood units. Br J Haematol 119: 773-776.

18. Fernandez MN, Regidor C, Cabrera R, Garcia-Marco J, Briz M. et al. (2001) Cord blood transplants: early recovery of neutrophils from co-transplanted sibling haploidentical progenitor cells and lack of engraftment of cultured cord blood cells, as ascertained by analysis of DNA polymorphisms. Bone Marrow Transplant, 28: 355-363.

19. Barker JN, Scaradavou A, Stevens CE (2010) Combined effect of total nucleated cell dose and HLA match on transplantation outcome in 1061 cord blood recipients with hematologic malignancies. Blood 115: 1843-1849.

20. Cutler C, Kim HT, Sun L, Sese D, Glotzbecker B, et al. (2011) Donorspecific anti-HLA antibodies predict outcome in double umbilical cord blood transplantation. Blood 118: 6691-6697.

21. Ruggeri A., Rocha V., Masson E., Labopin M., Cunha R. et al. Impact of donor specific anti-HLA antibodies on graft failure and survival after reduced intensity conditioning-unrelated cord blood transplantation. A Eurocord, Societe Francophone d'Histocompatibilite et d'Immunogenetique (SFHI) and Societe Francaise de Greffe de Moelle et de Therapie Cellulaire (SFGM-TC) analysis. Haematologica.

22. Takanashi M, Atsuta Y, Fujiwara K, Kodo H, Kai S, et al. (2010) The impact of anti-HLA antibodies on unrelated cord blood transplantations. Blood 116 2839-2846.
23. Ballen KK, Gluckman E, Broxmeyer HE (2013) Umbilical cord blood transplantation: the first 25 years and beyond. Blood 122: 491-498.

24. Shpall EJ, Quinones R, Giller R, Zeng C, Baron AE, et al. (2002) Transplantation of ex vivo expanded cord blood. Biol Blood Marrow Transplant 8: 368-376.

25. Pecora AL, Stiff P, Jennis A, Goldberg S, Rosenbluth R, et al. (2000) Prompt and durable engraftment in two older adult patients with high risk chronic myelogenous leukemia (CML) using ex vivo expanded and unmanipulated unrelated umbilical cord blood. Bone Marrow Transplant 25: 797-799.

26. Jaroscak J, Goltry K, Smith A, Waters-Pick B, Martin PL, et al. (2003) Augmentation of umbilical cord blood (UCB) transplantation with ex vivoexpanded UCB cells: results of a phase 1 trial using the AastromReplicell System. Blood 101: 5061-5067.

27. Pecora AL, Stiff P, LeMaistre CF, Bayer R, Bachier C, et al. (2001) A phase II trial evaluating the safety and effectiveness of the AastromReplicell system for augmentation of low-dose blood stem cell transplantation. Bone Marrow Transplant 28: 295-303.

28. de Lima M, McMannis J, Gee A, Komanduri K, Couriel D, et al. (2008) Transplantation of ex vivo expanded cord blood cells using the copper chelator tetraethylenepentamine: a phase I/II clinical trial. Bone Marrow Transplant 41 : 771-778.

29. McNiece IK, Almeida-Porada G, Shpall EJ, Zanjani E (2002) Ex vivo expanded cord blood cells provide rapid engraftment in fetal sheep but lack long-term engrafting potential. Exp Hematol 30: 612-616

30. Von Drygalski A, Alespeiti G, Ren L, Adamson JW (2004) Murine bone marrow cells cultured ex vivo in the presence of multiple cytokine combinations lose radioprotective and long-term engraftment potential. Stem Cells Dev 13: 101-111.

31. Delaney C, Heimfeld S, Brashem-Stein C, Voorhies H, Manger RL, et al. (2010) Notch-mediated expansion of human cord blood progenitor cells capable of rapid myeloid reconstitution. Nat Med 16: 232-236.

32. Williams DA (1993) Ex vivo expansion of hematopoietic stem and progenito cells--robbing Peter to pay Paul? Blood 81: 3169-3172.

33. Holyoake TL, Alcorn MJ, Richmond L, Farrell E, Pearson C et al. (1997) CD34 positive PBPC expanded ex vivo may not provide durable engraftment following myeloablative chemoradiotherapy regimens. Bone Marrow Transplant, 19: 1095-1101.

34. Tung SS, Parmar S, Robinson SN, De Lima M, Shpall EJ (2010) Ex vivo expansion of umbilical cord blood for transplantation. Best Pract Res Clin Haematol 23: 245-257.

35. Takizawa H, Schanz U, Manz MG (2011) Ex vivo expansion of hematopoietic stem cells: mission accomplished? Swiss Med Wkly 141: w13316.

36. McNiece I, Jones R, Bearman SI, Cagnoni P, Nieto Y, et al. (2000) Ex vivo expanded peripheral blood progenitor cells provide rapid neutrophil recovery after high-dose chemotherapy in patients with breast cancer. Blood 96: 30013007 .

37. McNiece I, Jones R, Cagnoni P, Bearman S, Nieto Y, et al. (1999) Ex-vivo expansion of hematopoietic progenitor cells: preliminary results in breast cancer. Hematol Cell Ther 41: 82-86.

38. Purdy MH, Hogan CJ, Hami L, McNiece I, Franklin W, et al. (1995) Large volume ex vivo expansion of CD34-positive hematopoietic progenitor cells for transplantation. J Hematother 4: 515-525.

39. Glimm H, Eaves CJ (1999) Direct evidence for multiple self-renewal divisions of human in vivo repopulating hematopoietic cells in short-term culture. Blood 94: 2161-2168.

40. Lazzari L, Lucchi S, Montemurro T, Porretti L, Lopa R, et al. (2001) Evaluation of the effect of cryopreservation on ex vivo expansion of hematopoietic progenitors from cord blood. Bone Marrow Transplant 28: 693-698.

41. Lazzari L, Lucchi S, Porretti L, Montemurro T, Giordano R, et al. (2001) Comparison of different serum-free media for ex vivo expansion of HPCs from cord blood using thrombopoietin, FIt-3 ligand, IL-6, and IL-11. Transfusion 41: 718-719.

42. Lazzari L, Lucchi S, Rebulla P, Porretti L, Puglisi G, et al. (2001) Long-term expansion and maintenance of cord blood haematopoietic stem cells using thrombopoietin, Flt3-ligand, interleukin (IL)-6 and IL-11 in a serum-free and stroma-free culture system. Br J Haematol 112: 397-404. 
43. Filip S, Vávrová J, Vokurková D, Bláha M, Vanásek J (2000) Myeloid differentiation and maturation of SCF+IL-3+IL-11 expanded AC133+/CD34+ cells selected from high-risk breast cancer patients. Neoplasma 47: 73-80.

44. Vavrova J, Filip S, Vokurkova D, Blaha M, Vanasek J et al. (1999) Ex vivo expansion CD34+/AC133+-selected autologous peripheral blood progenitor cells (PBPC) in high-risk breast cancer patients receiving intensive chemotherapy. Hematol Cell Ther, 41: 105-112.

45. Gammaitoni L, Weisel KC, Gunetti M, Wu KD, Bruno S, et al. (2004) Elevated telomerase activity and minimal telomere loss in cord blood long-term cultures with extensive stem cell replication. Blood 103: 4440-4448.

46. Piacibello W, Sanavio F, Garetto L, Severino A, Dané A, et al. (1998) Differential growth factor requirement of primitive cord blood hematopoietic stem cell for self-renewal and amplification vs proliferation and differentiation. Leukemia 12: 718-727.

47. Murray LJ, Young JC, Osborne LJ, Luens KM, Scollay R, et al. (1999) Thrombopoietin, flt3, and kit ligands together suppress apoptosis of human mobilized CD34+ cells and recruit primitive CD34+ Thy-1+ cells into rapid division. Exp Hematol 27: 1019-1028.

48. Young JC, Bruno E, Luens KM, Wu S, Backer M, et al. (1996) Thrombopoietin stimulates megakaryocytopoiesis, myelopoiesis, and expansion of CD34+ progenitor cells from single CD34+Thy-1+Lin- primitive progenitor cells. Blood 88: 1619-1631.

49. Fan J, Ding X, Jiang $Y$ (2012) A novel monoclonal antibody of human stem cell factor inhibits umbilical cord blood stem cell ex vivo expansion. J Hematol Oncol 5: 73 .

50. Jiang Y, Jiang W, Qiu Y, Dai W (2011) Effect of a structurally modified human granulocyte colony stimulating factor, G-CSFa, on leukopenia in mice and monkeys. J Hematol Oncol 4: 28.

51. Ma Y, Cui W, Yang J, Qu J, Di C, et al. (2006) SALL4, a novel oncogene, is constitutively expressed in human acute myeloid leukemia (AML) and induces AML in transgenic mice. Blood 108: 2726-2735.

52. Yang J, Chai L, Gao C, Fowles TC, Alipio Z, et al. (2008) SALL4 is a key regulator of survival and apoptosis in human leukemic cells. Blood 112: 805813.

53. Yang J, Chai L, Liu F, Fink LM, Lin P, et al. (2007) Bmi-1 is a target gene for SALL4 in hematopoietic and leukemic cells. Proc Natl Acad Sci U S A 104 10494-10499.

54. Lu J, Jeong HW, Kong N, Yang Y, Carroll J, et al. (2009) Stem cell factor SALL4 represses the transcriptions of PTEN and SALL1 through an epigenetic repressor complex. PLoS One 4: e5577.

55. Tang P, Sun H, Liu YF, Wang GY, Yin YF (2008) [Expression of SALL4 and BMI-1 mRNA in acute leukemia]. Zhongguo Shi Yan Xue Ye Xue Za Zhi 16: $1271-1274$.

56. Yang J, Chai L, Fowles TC, Alipio Z, Xu D, et al. (2008) Genome-wide analysis reveals Sall4 to be a major regulator of pluripotency in murine-embryonic stem cells. Proc Natl Acad Sci U S A 105: 19756-19761.

57. Aguila JR, Liao W, Yang J, Avila C, Hagag N, et al. (2011) SALL4 is a robus stimulator for the expansion of hematopoietic stem cells. Blood 118: 576-585.

58. Delaney C, Ratajczak MZ, Laughlin MJ (2010) Strategies to enhance umbilical cord blood stem cell engraftment in adult patients. Expert Rev Hematol 3: 273 283

59. Karanu FN, Murdoch B, Miyabayashi T, Ohno M, Koremoto M, et al. (2001) Human homologues of Delta-1 and Delta-4 function as mitogenic regulators of primitive human hematopoietic cells. Blood 97: 1960-1967.

60. Karanu FN, Murdoch B, Gallacher L, Wu DM, Koremoto M, et al. (2000) The notch ligand jagged-1 represents a novel growth factor of human hematopoietic stem cells. J Exp Med 192: 1365-1372.

61. Carlesso N, Aster JC, Sklar J, Scadden DT (1999) Notch1-induced delay of human hematopoietic progenitor cell differentiation is associated with altered cell cycle kinetics. Blood 93: 838-848.

62. Varnum-Finney B, Xu L, Brashem-Stein C, Nourigat C, Flowers D, et al. (2000) Pluripotent, cytokine-dependent, hematopoietic stem cells are immortalized by constitutive Notch1 signaling. Nat Med 6: 1278-1281.

63. Vas V, Szilágyi L, Pálóczi K, Uher F (2004) Soluble Jagged-1 is able to inhibit the function of its multivalent form to induce hematopoietic stem cell selfrenewal in a surrogate in vitro assay. J Leukoc Biol 75: 714-720.

64. Delaney C, Varnum-Finney B, Aoyama K, Brashem-Stein C, Bernstein ID (2005) Dose-dependent effects of the Notch ligand Delta1 on ex vivo differentiation and in vivo marrow repopulating ability of cord blood cells. Blood 106: 26932699.

65. Ohishi K, Varnum-Finney B, Bernstein ID (2002) Delta-1 enhances marrow and thymus repopulating ability of human CD34(+)CD38(-) cord blood cells. J Clin Invest 110: 1165-1174.

66. Wagner JE (2009) Should double cord blood transplants be the preferred choice when a sibling donor is unavailable? Best Pract Res Clin Haematol 22 $551-555$.

67. Dahlberg A, Delaney C, Bernstein ID (2011) Ex vivo expansion of human hematopoietic stem and progenitor cells. Blood 117: 6083-6090.

68. Schofield R (1978) The relationship between the spleen colony-forming cell and the haemopoietic stem cell. Blood Cells 4: 7-25.

69. Punzel M, Liu D, Zhang T, Eckstein V, Miesala K, et al. (2003) The symmetry of initial divisions of human hematopoietic progenitors is altered only by the cellular microenvironment. Exp Hematol 31: 339-347.

70. Zhang J, Niu C, Ye L, Huang H, He X, et al. (2003) Identification of the haematopoietic stem cell niche and control of the niche size. Nature 425: 836-841.

71. Dazzi F, Ramasamy R, Glennie S, Jones SP, Roberts I (2006) The role of mesenchymal stem cells in haemopoiesis. Blood Rev 20: 161-171.

72. Flores-Guzman P, Flores-Figueroa E, Montesinos JJ, Martinez-Jaramillo G, Fernandez-Sanchez V et al. (2009) Individual and combined effects of mesenchymal stromal cells and recombinant stimulatory cytokines on the in vitro growth of primitive hematopoietic cells from human umbilical cord blood. Cytotherapy, 11: 886-896.

73. Ehninger A, Trumpp A (2011) The bone marrow stem cell niche grows up: mesenchymal stem cells and macrophages move in. J Exp Med 208: 421-428.

74. Greenbaum A, Hsu YM, Day RB, Schuettpelz LG, Christopher MJ, et al. (2013) CXCL12 in early mesenchymal progenitors is required for haematopoietic stem-cell maintenance. Nature 495: 227-230.

75. Calvi LM, Adams GB, Weibrecht KW, Weber JM, Olson DP, et al. (2003) Osteoblastic cells regulate the haematopoietic stem cell niche. Nature 425 841-846.

76. Weber JM, Forsythe SR, Christianson CA, Frisch BJ, Gigliotti BJ, et al. (2006) Parathyroid hormone stimulates expression of the Notch ligand Jagged1 in osteoblastic cells. Bone 39: 485-493.

77. Duryagina R, Thieme S, Anastassiadis K, Werner C, Schneider S, et al. (2013) Overexpression of Jagged-1 and Its Intracellular Domain in Human Mesenchymal Stromal Cells Differentially Affect the Interaction with Hematopoietic Stem and Progenitor Cells. Stem Cells Dev.

78. Dexter TM (1982) Stromal cell associated haemopoiesis. J Cell Physiol Supp 1: $87-94$.

79. Deans RJ, Moseley AB (2000) Mesenchymal stem cells: biology and potential clinical uses. Exp Hematol 28: 875-884.

80. Zhang Y, Chai C, Jiang XS, Teoh SH, Leong KW (2006) Co-culture of umbilical cord blood CD34+ cells with human mesenchymal stem cells. Tissue Eng 12 2161-2170.

81. Jing D, Fonseca AV, Alakel N, Fierro FA, Muller K, et al. (2010) Hematopoietic stem cells in co-culture with mesenchymal stromal cells--modeling the niche compartments in vitro. Haematologica 95: 542-550.

82. Rodríguez-Pardo VM, Vernot JP (2013) Mesenchymal stem cells promote primitive phenotype CD34+c-kit+ in human cord blood-derived hematopoietic stem cells during ex vivo expansion. Cell Mol Biol Lett 18: 11-33.

83. Nishiwaki S, Nakayama T, Saito S, Mizuno H, Ozaki T, et al. (2012) Efficacy and safety of human adipose tissue-derived mesenchymal stem cells for supporting hematopoiesis. Int J Hematol 96: 295-300.

84. Song $\mathrm{K}$, Wang $\mathrm{H}$, Wang $\mathrm{H}$, Wang $\mathrm{L}$, Qiao $\mathrm{M}$, et al. (2011) Investigation of the effective action distance between hematopoietic stem/progenitor cells and human adipose-derived stem cells during their in vitro co-culture. Appl Biochem Biotechnol 165: 776-784. 
85. Vanikar AV, Dave SD, Thakkar UG, Trivedi HL (2010) Cotransplantation of adipose tissue-derived insulin-secreting mesenchymal stem cells and hematopoietic stem cells: a novel therapy for insulin-dependent diabetes mellitus. Stem Cells Int 2010: 582382

86. Hayashi N, Takahashi K, Abe Y, Kashiwakura I. (2009) Placental/umbilical cord blood-derived mesenchymal stem cell-like stromal cells support hematopoietic recovery of X-irradiated human CD34+ cells. Life Sci, 84: 598-605.

87. Huang GP, Pan ZJ, Jia BB, Zheng Q, Xie CG, et al. (2007) Ex vivo expansion and transplantation of hematopoietic stem/progenitor cells supported by mesenchymal stem cells from human umbilical cord blood. Cell Transplant 16 : $579-585$.

88. Mareschi K, Biasin E, Piacibello W, Aglietta M, Madon E, et al. (2001) Isolation of human mesenchymal stem cells: bone marrow versus umbilical cord blood. Haematologica 86: 1099-1100.

89. Wexler SA, Donaldson C, Denning-Kendall P, Rice C, Bradley B, et al. (2003) Adult bone marrow is a rich source of human mesenchymal 'stem' cells but umbilical cord and mobilized adult blood are not. $\mathrm{Br} \mathrm{J}$ Haematol 121: 368-374.

90. Wang HS, Hung SC, Peng ST, Huang CC, Wei HM, et al. (2004) Mesenchymal stem cells in the Wharton's jelly of the human umbilical cord. Stem Cells 22 1330-1337.

91. Weiss ML, Medicetty S, Bledsoe AR, Rachakatla RS, Choi M, et al. (2006) Human umbilical cord matrix stem cells: preliminary characterization and effect of transplantation in a rodent model of Parkinson's disease. Stem Cells 24 781-792.

92. Musina RA, Bekchanova ES, Belyavskii AV, Grinenko TS, Sukhikh GT (2007) Umbilical cord blood mesenchymal stem cells. Bull Exp Biol Med 143: 127-131.

93. Fong CY, Richards M, Manasi N, Biswas A, Bongso A (2007) Comparative growth behaviour and characterization of stem cells from human Wharton's jelly. Reprod Biomed Online 15: 708-718.

94. Fong CY, Subramanian A, Biswas A, Gauthaman K, Srikanth P, et al. (2010) Derivation efficiency, cell proliferation, freeze-thaw survival, stem-cell properties and differentiation of human Wharton's jelly stem cells. Reprod Biomed Online 21: 391-401.

95. Wenceslau CV, Miglino MA, Martins DS, Ambrosio CE, Lizier NF et al. (2011) Mesenchymal progenitor cells from canine fetal tissues: yolk sac, liver, and bone marrow. Tissue Eng Part A, 17: 2165-2176.

96. Robinson SN, Ng J, Niu T, Yang H, McMannis JD, et al. (2006) Superior ex vivo cord blood expansion following co-culture with bone marrow-derived mesenchymal stem cells. Bone Marrow Transplant 37: 359-366.

97. de Lima M, McNiece I, Robinson SN, Munsell M, Eapen M, et al. (2012) Cordblood engraftment with ex vivo mesenchymal-cell coculture. N Engl J Med 367 : 2305-2315.

98. Alakel N, Jing D, Muller K, Bornhauser M, Ehninger G, et al. (2009) Direct contact with mesenchymal stromal cells affects migratory behavior and gene expression profile of CD133+ hematopoietic stem cells during ex vivo expansion. Exp Hematol 37: 504-513.

99. Robinson SN, Simmons PJ, Yang H, Alousi AM, Marcos de Lima J, et al. (2011) Mesenchymal stem cells in ex vivo cord blood expansion. Best Pract Res Clin Haematol 24: 83-92.

100. Miller JS, Verfaillie C, McGlave P (1992) The generation of human natural kille cells from CD34+/DR- primitive progenitors in long-term bone marrow culture. Blood 80: 2182-2187.

101. McGlave P, Verfaillie C, Miller J (1994) Interaction of primitive human myeloid and lymphoid progenitors with the marrow microenvironment. Blood Cells 20 : 121-126.

102. Dick JE, Guenechea G, Gan OI, Dorrell C (2001) In vivo dynamics of human stem cell repopulation in NOD/SCID mice. Ann N Y Acad Sci 938: 184-190.

103. Guenechea G, Gan OI, Dorrell C, Dick JE (2001) Distinct classes of human stem cells that differ in proliferative and self-renewal potential. Nat Immuno 2: 75-82.

This article was originally published in a special issue, Thrombolic \& Thrombocyłopenic Purpurea handled by Editor(s). Dr. Han-Mou Tsai, Pennsylvania State University, USA.
104. Lemischka IR, Jordan CT (2001) The return of clonal marking sheds new light on human hematopoietic stem cells. Nat Immunol 2: 11-12

105. Shimizu Y, Ogawa M, Kobayashi M, Almeida-Porada G, Zanjani ED (1998) Engraftment of cultured human hematopoietic cells in sheep. Blood 91: 36883692.

106. Tisdale JF, Hanazono Y, Sellers SE, Agricola BA, Metzger ME, et al. (1998) Ex vivo expansion of genetically marked rhesus peripheral blood progenitor cells results in diminished long-term repopulating ability. Blood 92: 1131-1141.

107. Abkowitz JL, Taboada MR, Sabo KM, Shelton GH (1998) The ex vivo expansion of feline marrow cells leads to increased numbers of BFU-E and CFU-GM but a loss of reconstituting ability. Stem Cells 16: 288-293.

108. Peters SO, Kittler EL, Ramshaw HS, Quesenberry PJ (1996) Ex vivo expansion of murine marrow cells with interleukin-3 (IL-3), IL-6, IL-11, and stem cell factor leads to impaired engraftment in irradiated hosts. Blood 87: 30-37.

109.Peters SO, Kittler EL, Ramshaw HS, Quesenberry PJ (1995) Murine marrow cells expanded in culture with IL-3, IL-6, IL-11, and SCF acquire an engraftment defect in normal hosts. Exp Hematol 23: 461-469.

110. Flores-Guzman P, Fernandez-Sanchez V, Valencia-Plata I, Arriaga-Pizano $\mathrm{L}$, Alarcon-Santos $\mathrm{G}$ et al. (2013) Comparative in vitro analysis of different hematopoietic cell populations from human cord blood: in search of the best option for clinically oriented ex vivo cell expansion. Transfusion, 53: 668-678.

111. Glimm H, Eisterer W, Lee K, Cashman J, Holyoake TL, et al. (2001) Previously undetected human hematopoietic cell populations with short-term repopulating activity selectively engraft NOD/SCID-beta2 microglobulin-null mice. J Clin Invest 107: 199-206.

112. Manz MG, Miyamoto T, Akashi K, Weissman IL (2002) Prospective isolation of human clonogenic common myeloid progenitors. Proc Natl Acad Sci U S A 99: 11872-11877.

113. Bhatia M, Bonnet D, Kapp U, Wang JC, Murdoch B, et al. (1997) Quantitative analysis reveals expansion of human hematopoietic repopulating cells after short-term ex vivo culture. J Exp Med 186: 619-624.

114. Miettinen M, Lasota J (2005) KIT (CD117): a review on expression in norma and neoplastic tissues, and mutations and their clinicopathologic correlation. Appl Immunohistochem Mol Morphol 13: 205-220.

115. Strobl H, Takimoto M, Majdic O, Höcker P, Knapp W (1992) Antigenic analysis of human haemopoietic progenitor cells expressing the growth factor receptor c-kit. Br J Haematol 82: 287-294.

116. Edling CE, Hallberg B (2007) c-Kit--a hematopoietic cell essential receptor tyrosine kinase. Int J Biochem Cell Biol 39: 1995-1998.

117. Simmons PJ, Aylett GW, Niutta S, To LB, Juttner CA, et al. (1994) c-kit is expressed by primitive human hematopoietic cells that give rise to colonyforming cells in stroma-dependent or cytokine-supplemented culture. Exp Hematol 22: 157-165.

118. Isern J, Martín-Antonio B, Ghazanfari R, Martín AM, López JA, et al. (2013) Self-renewing human bone marrow mesenspheres promote hematopoietic stem cell expansion. Cell Rep 3: 1714-1724.

119. Simmons PJ, Torok-Storb B (1991) Identification of stromal cell precursors in human bone marrow by a novel monoclonal antibody, STRO-1. Blood 78: $55-62$.

120. Fong CY, Gauthaman K, Cheyyatraivendran S, Lin HD, Biswas A, et al. (2012) Human umbilical cord Wharton's jelly stem cells and its conditioned medium support hematopoietic stem cell expansion ex vivo. J Cell Biochem 113: 658668.

121. Friedman R, Betancur M, Boissel L, Tuncer H, Cetrulo C, et al. (2007) Umbilica cord mesenchymal stem cells: adjuvants for human cell transplantation. Bio Blood Marrow Transplant 13: 1477-1486.

122. Angelucci S, Marchisio M, Di Giuseppe F, Pierdomenico L, Sulpizio M, et al. (2010) Proteome analysis of human Wharton's jelly cells during in vitro expansion. Proteome Sci 8: 18.

Citation: Ren Z, Jiang Y (2013) Umbilical Cord Blood Hematopoietic Stem Cel Expansion Ex Vivo. J Blood Disorders Transf S3: 004. doi:10.4172/2155-9864. S3-004 